\title{
IMPLEMENTASI PEMBELAJARAN BERBASIS HOTS (HIGH ORDER THINKING SKILL) DI SEKOLAH DASAR KOTA MALANG
}

\author{
Antonius Alam Wicaksono ${ }^{1}$ Firsta Bagus Sugiharto ${ }^{2}$ \\ 1,2PGSD FIP Universitas Tribhuwana Tunggadewi \\ 1antoniuseducator@gmail.com, 2bagusfirsta@unitri.ac.id
}

\begin{abstract}
HOTS (High Order Thinking Skill) is material used by the students for helping the achievement of the competency standard, the purpose of education of primary and competence have (Depdiknas.2006) This study aims to describe the implementation of learning based on High Order Thinking Skills (HOTS) in Elementary Schools in Malang. It is well known that the implementation of the 2013 curriculum suggests that the importance of applying HOTS to the learning process in elementary schools. Therefore, it is necessary to conduct a study in the form of research to see the effectiveness of its implementation in elementary school. This research is a descriptive study with a qualitative approach. There are 2 methods used, namely descriptive and evaluative methods. The study population was all elementary schools in Malang. The research sample there are 40 public elementary schools in all districts in Malang. Data was collected using interview guidelines, observation sheets, and documentation. The results showed: (1) the average level of success of teachers in formulating HOTS-based learning planning in SD Malang only reached 79.46 even though it was in the Good category. (2) The average success rate of the implementation of HOTS-based learning as a whole is at $74.81 \%$ with the Fair category. (3) The average success rate of HOTS-based authentic assessment formulation in SD Malang is at $74.65 \%$ with the Fair category. Thus, improvement efforts are still needed, especially those related to the implementation of learning and authentic assessment of HOTS-based learning in Malang Primary School.
\end{abstract}

Keywords: HOTS, curriculum 2013, Primary School

\begin{abstract}
ABSTRAK
Penelitian ini bertujuan untuk mendeskripsikan tentang penerapan pembelajaran berbasis High Order Thinking Skills (HOTS) di Sekolah Dasar kota Malang. Telah diketahui bersama bahwa penerapan Kurikulum 2013 mengisyaratkan bahwa pentingnya penerapan HOTS pada proses pembelajaran di SD. Oleh sebab itu, perlu dilakukan studi berupa penelitian untuk melihat efektivitas pelaksanaannya di SD. Penelitian ini merupakan penelitian deskriptif dengan pendekatan kualitatif. Metode yang digunakan ada 2, yaitu metode deskriptif dan evaluatif. Populasi penelitian adalah seluruh SD yang ada di Kota Malang. Sampel penelitian ada 40 SD Negeri yang tersebar di seluruh kecamatan di kota Malang. Data dikumpulkan dengan menggunakan pedoman wawancara, lembar observasi, dan dokumentasi. Hasil penelitian menunjukkan: (1) tingkat keberhasilan guru dalam merumuskan perencanaan pembelajaran berbasis HOTS di SD kota Malang mencapai rata-rata
\end{abstract}


79,46 sehingga berada pada kategori Baik. (2) hasil rata-rata 74,81 dengan kategori cukup dalam pelaksanaan pembelajaran berbasis HOTS. (3) hasil kategori cukup dengan rata-rata $74,65 \%$ untuk keberhasilan perumusan penilaian autentik berbasis HOTS di SD kota Malang Dengan demikian, masih diperlukan upaya perbaikan, terutama yang berhubungan dengan pelaksanaan pembelajaran dan penilaian autentik pembelajaran berbasis HOTS di SD kota Malang.

Kata Kunci: HOTS, kurikulum 2013, Sekolah Dasar

\section{A. Pendahuluan}

Kemampuan berpikir adalah proses yang terjadi di dalam alam mental dan psikis setiap insan generasi pembelajar, dimana pada fase ini diperlukan adanya pengetahuan dan pengalaman sebagai landasan yang fundamental. Kemampuan berpikir bertujuan untuk mencari makna dan pemahaman tentang sesuatu, mengeksplorasi ide, mengambil keputusan, memikirkan pemecahan masalah dengan pertimbangan terbaik, dan merevisi permasalahan pada proses berpikir sebelumnya. Sebagaimana yang telah dijelaskan bahwa thinking skill is an ability in using mind to find meaning and comprehension on something, exploration of ideas, making decision, problem solving with best consideration and revision on the previous thinking process (Arifin, 2017). Nursaila (2015) menjelaskan bahwa "Thinking skills is a knowledge discipline that can be learned and practised until form norm or experience." Kemampuan berpikir secara umum bersifat abstrak, tidak bisa dilihat, sebelum dibuktikan dengan aktivitas yang konkret. Sehingga kemampuan berpikir akan nampak bila diwujudkan dalam sebuah aktivitas yang konkret, berbasis pada pengalaman belajar, dan terkonstruk pada norma-norma.

Pembelajaran berbasis HOTS pada Kurikulum 2013 dapat dilakukan dengan menyusun pencapaian kompetensi yang tidak hanya menjawab pada level C-1 (mengetahui), C-2 (memahami), dan C-3 (menerapkan), tetapi juga pada level C-4 (sintesis/ analisis), C-5 (evaluasi), dan C-6 (berkreasi). Belajar berpikir kritis sebagai ciri dari HOTS tidak seperti belajar tentang materi secara langsung. Berpikir kritis adalah berkaitan dengan bagaimana memecahkan masalah yang saling berkaitan satu dengan lainnya. Berpikir kritis memungkinkan siswa untuk menemukan kebenaran di tengah kejadian dan informasi yang 
mengelilingi mereka setiap hari. Melalui berpikir kritis, siswa akan mengalami proses sistematis yang memungkinkan meraka untuk merumuskan dan mengevaluasi keyakinan dan pendapat mereka sendiri.Penelitian terkait pembelajaran dengan pendekatan CTL pernah dilakukan oleh Septy Indriyasari bahwa melalui metode Contextual Teaching Learning (CTL) dapat meningkatkan prestasi belajar menulispuisi pada siswa kelas III SD I Palbapang.

Layaknya sebagai suatu kebijakan publik, implementasi pembelajaran berbasis HOTS di SD sesuai dengan tuntutan Kurikulum 2013 perlu ditinjau efektivitas pelaksanaannya di berbagai daerah, tidak terkecuali di kota Malang. Hal ini bertujuan untuk memproleh data dan informasi akurat terkait dengan kelemahan dan kekuatan implementasi pembelajaran berbasis HOTS pada jenjang SD. Berdasarkan data itu kemudian muncul kebijakan baru terkait dengan upaya mengatasi dan mencegah kelemahan implementasinya serta upaya meningkatkan kekuatan yang dimilikinya. Berdasarkan kajian inilah kemudian dapat dilakukan perumusan dan pengawasan kebijakan sebagai upaya optimalisasi pembelajaran berbasis HOTS di SD, khususnya di Kota Malang.

\section{B. Metode Penelitian}

Penelitian ini bertujuan untuk mendeskripsikan implementasi pembelajaran berbasis HOTS di SD kota Malang. Dari hasil penelitian tersebut diperoleh data mengenai efektivitas implementasi pembelajaran berbasis HOTS di SD kota Malang terutama yang berhubungan dengan perencanaan, pelaksanaan, penilaian autentik, faktor pendukung, dan faktor penghambatnya. Karenanya, penelitian ini merupakan penelitian deskriptif dengan pendekatan kualitatif.

Metode penelitian deskriptif, digunakan dalam penelitian awal untuk menghimpun data tentang kondisi yang ada. Kondisi yang ada mencakup: (1) kondisi sekolah, kompetensi guru, kompetensi kepala sekolah, dan karakteristik siswa; (3) kondisi faktor-faktor pendukung dan penghambat pengembangan pembelajaran berbasis HOTS di SD, misalnya saja sarana dan prasarana pendukung. 


\section{Hasil Penelitian dan Pembahasan}

Bagian ini peneliti akan menjelaskan temuan hasil penelitian menganai

Implementasi

Pembelajaran Berbasis HOTS (High

Order Thinking Skill) di Kota Malang. Hasilnya adalah terdapat 4 aspek fokus kajian yang dilakukan pada kegiatan penelitian, antara lain yaitu: perencanaan pembelajaran, pelaksanaan pembelajaran, penilaian, faktor pendukung dan faktor penghambat. Berikut akan dijabarkan secara komprehensif hasil penelitian:

\section{Perencanaan pembelajaran}

Instrumen yang digunakan dalam menganalisis rumusan perencanaan pembelajaran adalah RPP (Rencana Pelaksanaan Pembelajaran). Analisis dilakukan pada stiap komponen dan tingkat kebenaran dokumen rencana pembelajaran yang mana data tersebut dapat dilihat pada tabel 1 berikut:

Tabel 1. Hasil Analisis Perencanaan Pelaksanaan Pembelajaran Berbasis HOTS di Kota Malang

\begin{tabular}{|c|c|c|c|}
\hline No. & Kualifikasi & $\begin{array}{c}\text { Jumlah } \\
\text { Guru }\end{array}$ & $\begin{array}{c}\text { Persentase } \\
(\%)\end{array}$ \\
\hline 1. & Sangat Baik & 10 & 12,5 \\
\hline 2. & Baik & 50 & 62,5 \\
\hline 3. & Cukup & 16 & 20 \\
\hline 4. & Kurang & 4 & 5 \\
\hline \multicolumn{3}{|c|}{ Nilai Rata-rata } & 79,46 \\
\hline \multicolumn{3}{|c|}{ Kualifikasi } & Baik \\
\hline
\end{tabular}

Berdasarkan pada tabel 1 bisa dilihat banyak guru yang merumuskan perencanaan pembelajaran berbasis HOTS dengan kualifikasi sangat baik yaitu sejumlah 10 orang dengan persentase mencapai 12,5\%. Guru dengan kualifikasi baik sejulah sejumlah 50 orang dengan persentase $62,5 \%$. Guru dengan kualifikasi cukup sejumlah 16 orang dengan persentase $20 \%$. Sedangkan guru dengan kualifikasi kurang dalam perencanaan pembelajaran HOTS sejumlah 4 orang dengan persentase 4\%. Sehingga tingkat keberhasila guru dalam merancang Rencana Pelaksanaan Pembelajaran berbasis HOTS di Kota Malang secara keseluruhan adalah Baik bila melihat jumlah persentase terbesar.

Instrumen yang digunakan untuk mengobservasi efektivitas pelaksanaan pembelajaran yang berorientasi pada HOTS adalah IPKG2 (Instrumen Penilaian Kinerja Guru 2/ Pelaksanaan Pembelajaran). Hasil analisis terhadap pelaksanaan pembelajaran berbasis HOTS dapat dilihat secara rinci pada Tabel 2 di bawah. 
Tabel 2. Hasil Analisis Pelaksanaan Pembelajaran Berbasis HOTS di SD Kota Malang

\begin{tabular}{|c|c|c|c|}
\hline No & Kualifikasi & $\begin{array}{c}\text { Banyak } \\
\text { Guru }\end{array}$ & $\begin{array}{c}\text { Persenta } \\
\text { se } \\
(\%)\end{array}$ \\
\hline 1 & $\begin{array}{c}\text { Sangat } \\
\text { Baik }\end{array}$ & 4 & 5 \\
\hline 2 & Baik & 30 & 37,5 \\
\hline 3 & Cukup & 42 & 52,5 \\
\hline 4 & Kurang & 4 & 5 \\
\hline \multicolumn{3}{|c|}{ Nilai Rata-rata } & $\mathbf{7 4 , 8 1}$ \\
\hline \multicolumn{3}{|c|}{ Kualifikasi } & Cukup \\
\hline
\end{tabular}

Jika diterjemahkan lebih lanjut, Tabel 2 mendeskripsikan sebagai berikut: (1) guru yang melaksanakan proses pembelajaran berbasis HOTS dengan kategori Sangat Baik ada 4 orang dan jika dipersentasekan ada $5 \%$ dari 80 orang guru yang menjadi sampel penelitian, (2) banyak guru yang melaksanakan proses pembelajaran berbasis HOTS dengan kategori Baik ada 30 orang dan jika dipersentasekan ada $37,5 \%$, banyak guru yang melaksanakan proses pembelajaran berbasis HOTS pada kategori Cukup Baik ada 42 orang dan jika dipersentasekan ada $52,5 \%$, (4) banyak guru yang melaksanakan proses pembelajaran dengan kategori Kurang Baik ada 5 orang dan jika dipersentasekan ada $5 \%$ dari total keseluruhan, dan (5) tingkat keberhasilan implementasi pembelajaran berbasis HOTS secara keseluruhan berada pada $74,81 \%$ dengan kategori Cukup. Artinya, secara umum pelaksanaan pembelajaran berbasis HOTS di SD kota Malang masih berada pada kategori Cukup dan masih perlu ditingkatkan.

Penilaian autentik menitikberatkan pada dua aspek penilaian, yaitu: instrumen penilaian yang digunakan dan implementasinya dalam proses pembelajaran. Temuan hasil penelitian berdasarkan analisis instrumen yang digunakan, penilaian autentik pada pembelajaran berbasis HOTS di SD kota Malang dapat dilihat secara rinci pada Tabel 3 berikut

Tabel 3. Hasil Analisis Penilaian

Autentik Berbasis HOTS di SD Kota Malang

\begin{tabular}{|c|c|c|c|}
\hline No & $\underset{\text { asi }}{\text { Kualifik }}$ & $\begin{array}{c}\text { Banyak } \\
\text { Guru }\end{array}$ & $\begin{array}{l}\text { Persenta } \\
\text { se } \\
\quad(\%)\end{array}$ \\
\hline 1 & $\begin{array}{l}\text { Sangat } \\
\text { Baik }\end{array}$ & 8 & 10 \\
\hline 2 & Baik & 32 & 40 \\
\hline 3 & Cukup & 36 & 45 \\
\hline 4 & Kurang & 4 & 5 \\
\hline \multicolumn{3}{|c|}{ Nilai Rata-rata } & 74,65 \\
\hline \multicolumn{3}{|c|}{ Kualifikasi } & Cukup \\
\hline
\end{tabular}


Berdasarkan sebaran data pada Tabel 3 diperoleh simpulan sebagai berikut: (1) banyak guru yang mampu merumuskan penilaian autentik berbasis HOTS di SD kota Malang dengan kategori Sangat Baik ada 8 orang atau $10 \%$ dari jumlah total keseluruhan, (2) banyak guru yang mampu merumuskan penilaian autentik berbasis HOTS dengan kategori Baik ada 32 orang atau berada pada $40 \%$ dari total keseluruhan, (3) banyak guru yang merumuskan penilaian autentik berbasis HOTS dengan kategori Cukup ada 36 orang atau lebih kurag $45 \%$ dari total keseluruhan, dan (4) ada 4 orang guru yang berada pada kategori Kurang dalam merumuskan penilaian autentik berbasis HOTS di SD, serta (5) tingkat keberhasilan perumusan penilaian autentik berbasis HOTS di SD kota Malang berada pada $74,65 \%$ dengan kategori Cukup. Sama halnya dengan pada pelaksanaan pembelajaran, rumusan penilaian autentik pun masih berada pada kategori Cukup.
Tabel 4. Faktor Pendukung dan

Penghambat Implementasi HOTS di Sekolah Dasar

\begin{tabular}{|c|c|c|}
\hline No & Faktor Pendukung & Faktor Penghambat \\
\hline 1. & $\begin{array}{l}\text { Sarana dan prasarana yang } \\
\text { cukup }\end{array}$ & $\begin{array}{l}\text { Pemahaman guru tentang cara } \\
\text { merumuskan indikator masih } \\
\text { kurang }\end{array}$ \\
\hline 2. & $\begin{array}{l}\text { Persepsi guru yang positif } \\
\text { terahdap implementasi } \\
\text { pembelajaran berbasis HOTS di } \\
\text { SD }\end{array}$ & $\begin{array}{l}\text { Sekolah masih tahap awal } \\
\text { implementasi kurikulum } 2013\end{array}$ \\
\hline 3. & $\begin{array}{l}\text { Dukungan dan komitmen yang } \\
\text { cukup dari Dinas Pendidikan } \\
\text { Kota Malang dan Kepala } \\
\text { SEKolah mampu untuk } \\
\text { meningkatkan kualitas } \\
\text { pendidikan terutama penerapan } \\
\text { pembelajaran berbasis HOTS di } \\
\text { SD }\end{array}$ & $\begin{array}{l}\text { Pemahaman guru tentang konsep } \\
\text { dan penerapan HOTS dalam } \\
\text { pembelajaran masih kurang }\end{array}$ \\
\hline 4. & $\begin{array}{l}\text { Karakteristik siswa yang berada } \\
\text { di perkotaan yang cenderung } \\
\text { lebih aktif dalam pembelajaran }\end{array}$ & $\begin{array}{l}\text { Pelatihan dan pendampingan } \\
\text { tentang HOTS masih minim } \\
\text { diperoleh }\end{array}$ \\
\hline 5. & $\begin{array}{l}\text { Kualifikasi pendidikan guru } \\
\text { yang sudah memadai }\end{array}$ & $\begin{array}{l}\text { Pendampinagn yang berorientasi } \\
\text { pada contoh penerapan secara } \\
\text { langsung kuranng diperoleh } \\
\text { (masih terlalu teoritis) }\end{array}$ \\
\hline
\end{tabular}

\section{Kesimpulan}

1. Rata-rata tingkat keberhasilan guru dalam merumuskan perencanaan pembelajaran berbasis HOTS di SD kota Malang baru mencapai 79,46 meskipun sudah berada pada kategori Baik.

2. Rata-rata tingkat keberhasilan pelaksanaan pembelajaran berbasis HOTS secara keseluruhan berada pada $74,81 \%$ dengan kategori Cukup.

3. rata-rata tingkat keberhasilan perumusan penilaian autentik berbasis HOTS di SD kota Malang berada pada $74,65 \%$ dengan kategori Cukup. (4) Faktor pendukung implementasi pembelajaran berbasis HOTS di SD kota Malang, antara lain: (a) sarana dan prasarana yang cukup memadai, (b) persepsi guru yang positif terhadap implementasi pembelajaran berbasis HOTS di SD, (c) dukungan dan komitmen 
yang dari Dinas Pendidikan Kota Malang dan Kepala Sekolah untuk meningkatkan kualitas pendidikan terutama penerapan pembelajaran berbasis HOTS di SD, (d) karakteristik siswa yang berada di perkotaan yang cenderung lebih aktif dalam pembelajaran, (e) Kualifikasi pendidikan guru yang sudah memadai. Faktor penghambat implementasi pembelajaran berbasis HOTS di SD kota Malang sebagai berikut: (a) pemahaman guru tentang cara merumuskan indikator masih kurang, (b) sekolah masih tahap awal implementasi kurikulum 2013, (c) pemahaman guru tentang konsep dan penerapan HOTS dalam pembelajaran masih kurang, (d) pelatihan dan pendampingan tentang HOTS masih minim diperoleh, dan (e) pendampingan yang berorientasi pada contoh penerapan secara langsung kurang diperoleh (masih teoritis). Dengan demikian, masih diperlukan upaya perbaikan terutama yang berhubungan dengan pelaksanaan pembelajaran dan penilaian autentik pembelajaran berbasis HOTS di SD kota Malang.

\section{DAFTAR PUSTAKA}
Ahmad, Shaleh
Nazili. 2011.
Pendidikan dan Masyarakat. Yogyakarta: Sabda.
Alam, A. W., \& Bariska, H. F. (2019).
Pengembangan Buku Ajar
Bahasa Indonesia Berbasis

Pendidikan Karakter Dengan Model Assure Pada Siswa Sekolah Dasar. Pendas: Jurnal IImiah Pendidikan Dasar, 3(2), 123-132.

Wicaksono, A. A., \& Bariska, H. F. (2018). Pengembangan Buku Teks Bahasa Indonesia Berbasis Budaya Jawa Timur Dengan Model Pakem Untuk Peningkatan Hasil Belajar Siswa Kelas IV Sekolah Dasar. JURNAL PENDIDIKAN DASAR NUSANTARA, 3(2), 144-151.

H.A.R. Tilaar. $2002 . \quad$ Membenahi Pendidikan Nasional. Jakarta: PT. Rineka Cipta

Muhadjir Darwin (eds). (2010).Dinamika kependudukan dan penguatan governance. Yogyakarta: Media Wacana

Miri, B. et al. (2007). "Purposely Teaching for the Promotion of Higher-Order Thinking Skills: A Case of Critical Thinking." Res Sci Educ, 37 (1), 353-369.

Jennifer L. S. R., et al. (2013). "Higher Order Thinking Skills and Academic Performance in Physics of College Students: A Regression Analysis." International Journal of Innovative Interdisciplinary Research, 12 (4), 48-60.

Kurniati,

Euis.2016.Permainan Tradisional dan Perannya Keterampilan Sosial Anak. Jakarta : Prenamedia Group 
Kuswana, Wowo Sunaryo. 2012.

Taksonomi Kognitif. Bandung:

PT. Remaja.

Nursaila, S., dan Faridah. (2015). "Problem Solving Strategy in Balanced Forces." International Journal of Bussiness and Social Science, Vol. 6 (8), 94-98.

Panpan Achmad Fadjri. (2000). Analisis kualitas sumber daya manusia menurut kota di Indonesi a", Warta Demografi, 30 No.3: 34-39.

Saputra Alanindra. 2016. "Analisis Keterampilan Proses Sains (KPS) Dasar Mahasiswa Calon Guru Biologi Pada Mata Kuliah Anatomi Tumbuhan (Studi Kasus Mahasiswa Prodi Pendidikan Biologi FKIP UMS Tahun Ajaran 2015/2016)". Prosiding seminar nasional pendidikan sains (SNPS). Surakarta: Universitas Muhammadiyah Surakarta.

Saroni, Muhammad. (2006). Lingkungan Sekolah dan Pengembangannya. Jakarta PT.Raja Grafindo Persada.

Soesmono Hadi. 2008. Pendidikan (Suatu Pengantar). Surakarta : LPP UNS dan UNS Press

Widodo. 2013. Psikologi Belajar. Jakarta : PT. Rineka Cipta 